Journal of Business \& Management (COES\&RJ-JBM)

ISSN (E): 2306-7179 ISSN (P): 2306-8043

Publisher: Centre of Excellence for Scientific \& Research Journalism, COES\&RJ LLC

Online Publication Date \& Issue: 1st Jan. 2020, Vol.8, No.1, January 2020

https://doi.org/10.25255/jbm.2020.8.1.20.34

\title{
Effect of Training and Development on Employee Performance in the Aqaba Special Economic Zone Authority
}

\author{
Shaker H. Alnawfleh \\ Aqaba Special Economic Zone Authority, Aqaba, Jordan \\ shalnawafleh@aseza.jo
}

\section{Abstract:}

This study was conducted to identify the effect of training and development on Employee Performance in the Aqaba Special Economic Zone Authority. Random sampling technique was used to collect data for this research study. A developed questionnaire was distributed among 112 employees in the Aqaba Special Economic Zone Authority for data collection. To check the effect of training and development on employee's performance, descriptive statistical technique and ttestwas applied on the data. The results indicate that there was a significant difference in scores for trained employees and untrained employees with large effect, (30\%) of the employees' performance isexplained by training and development programs. It is proved that independent variables contribute positively towards change in the dependent variable.

Keywords:

Training and Development, Employee performance and Aqaba Special Economic Zone Authority

\section{Citation:}

Alnawfleh, Shaker H. (2020); Effect of Training and Development on Employee Performance in the Aqaba Special Economic Zone Authority; Journal of Business \& Management (COES\&RJ-JBM) Vol.8, No.1, pp.20-34, https://doi.org/10.25255/jbm.2020.8.1.20.34. 


\section{Introduction}

\subsection{Background}

Since the establishment of the Aqaba Special Economic Zone Authority in the early period of this century, the administration of the Authority represented by the department of human resources has been work hardly to increase the level of performance and professionalism of its employees, based on scientific issues and up dated methods which could improve the level of performance of its employees and the positive impact on the level of service provided by them in order to obtain a higher level of satisfaction of the Authority's services customers.

Worldwide, the organizational performance is not a single action (Masa'deh, et al., 2015; Abualoush, et al., 2018a, b; Al-dalahmeh, et al., 2018; Padmasiri, 2018); it's a multi-component concept (Pradhan, \& Jena, 2017). It's mainly depend on employees' participation (Jain, \& Sharma, 2019), because human resources are blood stream of any organization (Elnaga, \& Imran, 2013) and play an important part in the organizational growth (Said, 2015). By other words, to achieve the desired organizational performance, the organizational managers should keep in mind the importance of coordination between manager and subordinate in order to achieve short-term and long-term organizational objectives, and to refer the efforts of all employees directly for the optimal organizational goals (Jain, \& Sharma, 2019).

Employees considered an essential part of each organization (Masa'deh, 2012; Hafeez, \& Akbar, 2015), so the employees are expected to be qualified and having an experience and competent to complete their tasks effectively (AlDmour, et al., 2015; Hidayat, \& Budiatma, 2018). Some employees don't have the necessary knowledge and skills to achieve the requested goals effectively, and need for more Training and Development (T\&D) programs to met the desired goals (Sanyal, \& Hisam, 2018). As a result, the importance of training and developing programs emerged to help the employees to achieve their work excellently and professionally (Khan, et al. 2017).

Organizations invest in the T\&D programs for their employees with anticipation for positive effect of these programs in the organizational performance (Shen, \& Tang, 2018). Similar expectations from T\&D programs are to empower the motivation of the employees in improving their performance skills (Hidayat, \& Budiatma, 2018). Training and development is a crucial activity in for any organization, it have several benefits among the employees and the organization in general, T\&D was associated with integrity of employees performance, more work satisfaction, higher customer satisfaction, and more benefits (Jaworski, et al. 2018). 


\subsection{Problem statement}

Each employee who attends to any training program has a goal of obtaining a new knowledge or skills, and he/she hopes that these knowledge or skills could help to increase the benefit from his work and to have more promotions on his work (Shen, \& Tang, 2018).

Many factors that maybe affect employee performance and achievements, such as leadership, work culture, work punctuality, work motivation, T\&D programs, and innovation (Hajir, et al., 2015; Al-Syaidh, et al., 2016; Obeidat, et al., 2017; Hidayat, \& Budiatma, 2018). Unfortunately, organizations don't tend to do at least a little bit effort in the implementation of an effective T\&D programs (Jaworski, et al. 2018). Consequently, knowledge on the honest relationships among T\&D programs and employee work outcomes is limited. More research is necessary to give more views on the relationship between theT\&D programs and employee performance (Shen, \& Tang, 2018).

\subsection{Significance of the study}

To address the gap between the prevailing assumption and mixedempirical evidence on the value of $T \& D$, the present study investigatesthe distinct functions associated with different dimensions of T\&D, their intermediate employee outcomes (Sung, \& Choi, 2018). The outcomes of this research will help and support the banks to identify the Training and Developmentfactors that influence the employee performance in the banking organizations. On the other hand, the research will be helpful in the department of human resource of every organization which is trying to increase the productivity of their employees (Sanyal, \& Hisam, 2018).

\subsection{Purpose and research questions}

This paper studies the effect of Training and developmenton Employee Performance in the Aqaba Special Economic Zone Authority. To achieve this goal, the researcher focuses on a number of objectives:

1. To examine the impact of T\&Don employee performance.

2. To evaluate the T\&Dprograms that was provided by the Aqaba Special Economic Zone Authority.

3. To identify the level of performance for the employees.

These objectives guided the researcher to identify the following research questions:

1) Is there an effect of T\&D on Employee Performance in the Aqaba Special Economic Zone Authority?

2) How did the employees evaluate the T\&D programs which provided by the authority?

3) How did the employees see theirlevel of performance? 


\subsection{Study variables and framework}

This study was involved two major variables:

\subsubsection{Training and development:}

Training is learn a specific skill to do a certain job (Sanyal, \& Hisam, 2018) while development deals with general increasing and evolution of individual skill and capacity through conscious and unconscious learning (Armstrong, 2009).

The developed items classified into threedistinguished groups: task performance (e.g., "I use to maintain high standard of work"), adaptive performance (e.g., "I use to keep myself updated with new skills and knowledge that help me to quickly adapt to changes in my core jobs"), and contextual performance (e.g., "I use to guide my new colleagues beyond my job purview") (Pradhan, \& Jena, 2017).

Training and developmentis refers to "a series of organized activities conducted within a specified time and designed to produce behavioral change" (Sung, \& Choi, 2018).

\subsubsection{Employee performance:}

Its job related activities anticipated of a worker and how well those activities were carried out, it could be assessed annually or quarterly basis in order to help them recognize suggested areas for improvement (Businessdictionary.com).

\section{Study framework}

For helping the researcher to achieve the study goal, the researcher develops the following study framework:

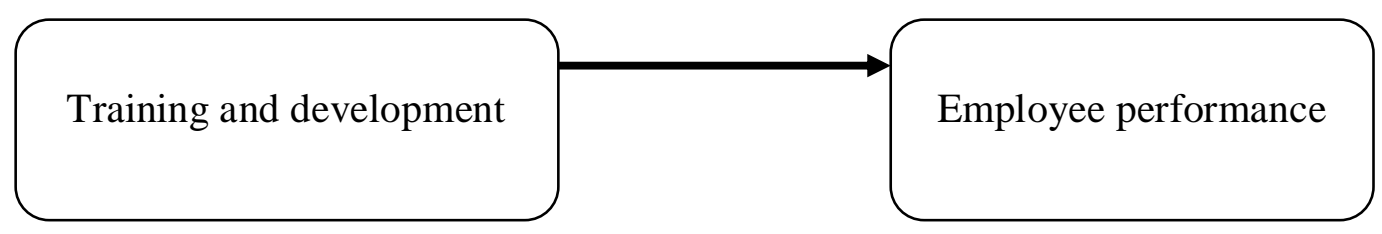

Source: Author

\section{Literature Review}

\subsection{Training and development}

The direct effect of T\&D on company innovative performance is considerable not only for company development, but it significant for employee positive recognition of T\&D, these effect was concluded from a study conducted on 2018 by Sung, \& Choi among (325) of Korean organizations. Abba, M. T. conducted a research tostudy the effect of T\&D on the organizational goals among Nigerian employees, and the results support that the satisfied employees can achieve 
organizational goals effectively, and conclude that there was a significance relationship between T\&D and the employees' satisfaction and retention (Abba, 2018).

Job training and its effects were studied among Pakistani employees by Khan, et al., and the results shows that the job training has a positive effect on the employee productivity (Khan, et al. 2017). Another study conducted on china, among (230) employees, to explore the effect of T\&D on the customer service quality and concludes that the customer service quality will improveindirectly by improving in the job satisfaction which affected by T\&D programs (Shen, \& Tang, 2018).

\subsection{Employee performance}

Many researchers were interested to study the factors which affected the employee performance, such as a research conducted by Hassan, S. to study the impact of human resources manger practices on the employee performance among 68 employees in Pakistan, and the results shows a positive impact of human resources manger practices on the employee performance (Hassan, 2016). Another study was conducted in Indonesia to evaluate the effect of education and job training on employee performance among (105) employees, the results was concluded a significant effect of education on employee performance (Hidayat, \& Budiatma, 2018).

\subsection{Effect of training and development on employee performance}

On the another hand, the effect of training and development on employee performance form a rich environment for studies and research, such as a study was conducted by Sanyal, \& Hisam, to evaluate the training and development on employee performance among (300) employees in the Omani Banking Industry, and conclude that there was a positive influence on employee performance by training and development programs (Sanyal, \& Hisam, 2018). A similar study conducted in Sri Lanka, to identify the relationship between training and development and employee performance for (150) executive employees, and reported that there was a positive relationship between training and development and employee performance (Padmasiri, 2018).

In Nigeria, a descriptive study conducted by Yetunde to investigate the impact of training and development on the employee performance for (76) employee, and the result shows that there was a significant relationship between training and development and the employee performance (Yetunde, 2018). A comparable study was conducted by Said, C.M. to assess the impact of training and development and the employee performance for (65) employees from Kenya, and report that the training and development influence the employee performance in a significance degree (Said, 2015). 


\section{Methodology}

\subsection{Research design}

This study used a descriptive, correlational, cross-sectional design to assess effect of T\&D programs on employee performance among the employees in the Aqaba Special Economic Zone Authority, evaluate the T\&D programs that were provided for them and to identify the level of performance of employees.

\subsection{Population and sample}

The accessible population of the study was all employees in theAqaba Special Economic Zone Authority. The sample size was calculated using G-power program with aprobability of (5\%) and power of (80\%), with a medium effect size of $(0.5)$, so the calculating program indicated the minimum number of sample is (51) employees for each group, one group was received T\&D programs within the last 3 years and the another group was didn't T\&D programs in the same period of time, and to minimize the effect of errors, this study involved (110) employees in the two groups.

\subsection{Instrument of data collection}

In order to achieve the goal of the study and based on previous literature, the researcher designed the study questionnaire, which was consist of four parts; the firstpart was for the demographical characteristics of the employees, the second part was for evaluation for the T\&D programs (which were previously provided for the employees in the last 3 years), the third part was for effect of the T\&D programs from the employees viewand finally the fourth part was a copy of Selfevaluation scale for employees, all was on Likert 5 Rating Scale.

For collecting the data, convenience sampling technique was used to distribute the questionnairefor the two groups of the employees. But before conducting the study, pilot testing is done by taking 12 employees for the purpose of checking the reliability of the questionnaire.

The tool was piloted using 12 ( 6 was involved in T\&D programs in the last 3 years and 6 wasn't) employees. The responses of respondents were scored and the reliability of theinstrument was determined using Cronbach's Alpha. According to the alpha value more than 0.6 , shows that the scale can be considered reliable (Asfaw, et al., 2015). The instrument has (31) questions: (10) questions for evaluation of T\&D programs, (13) questions for effect of T\&D programs on employee performance and (8) questions for self-evaluation of employee performance. The result shows that the Cronbach's alpha ranges from (.768) to (.918) which show the scale is reliable, as in table (1). 
Effect of Training and Development on Employee Performance...

Table 1. The instrument reliability

\begin{tabular}{|l|l|l|l|}
\hline & Variables & No of items & Alpha value \\
\hline 1 & Evaluation of T\&D programs & 10 & .918 \\
\hline 2 & $\begin{array}{l}\text { Effect of T\&D programs on employee } \\
\text { performance }\end{array}$ & 13 & .768 \\
\hline 3 & Self-evaluation of employee performance & 8 & .899 \\
\hline
\end{tabular}

Prepared by researcher depend on pilot study results

\subsection{Data analysis}

After collecting the valid questionnaires and calculating the response rate, the data has been coded manually and entered to Statistical Package for SocialSciences (SSPS version 21) data base. Descriptive statistics (mean and standard deviation) were used to the employee's demographical characteristics. Inferential statistic (t-test) was used for testing the effect of T\&D programs on employee performancefor research question number one. Another Descriptive statistics (mean and standard deviation) used to summarize the employees evaluation of the T\&D programs which provided by the authorityfor research question number two, and usedto summarized the employees Self-evaluation for level of performancefor research question number three.

\subsection{Ethical considerations}

This study got the approval of theAqaba Special Economic Zone Authority to conduct this study among the Authority employees. Informed consent has been obtained for each participant with ensuring the confidentiality and anonymity and ensuring that the participating is voluntary; the participant could withdraw at any time during the data collection time. There is no risk on the involved employees and no financial issues in participating in this study. The researcher phone number was mentioned, for any questions, or any help for the participants in filling out the questionnaire.

\section{Results}

\subsection{Demographical information}

The researcher distributed (120) questionnaires among the employees in the Aqaba Special Economic Zone Authority. Only (112) questionnaires were valid for analysis, making the response rate of $93.3 \%$.

Table (2) shows that, out of (112) employees participated in this study; almost the majority of the participants $(58.9 \%)$ were male. The half of the participants $(52.7 \%)$ was married. The age of more than $(42 \%)$ of the participants were 
ranged from (20-29) years old. The educational levels for the employees indicated that (46.4\%) were has BCS degree, and (32.2\%) of the participants were has higher education. Furthermore, the majority of participants (72.4\%) have been worked for less than (7) yearsof experience in the Aqaba Special Economic Zone Authority. In relation to the research topic, and to help researcher in the answer of the research questions, the participants who had T\&D programs were $(53.6 \%)$ of the study participants. The analysis of the frequency of the T\&D programs for the employees shows that the majority of the participants (41\%) were received two T\&D programs for the last 3 years.

Table 2. Soico-demographic information of about the respondents $(\mathrm{N}=112)$

\begin{tabular}{|c|c|c|c|}
\hline Category & Component & Frequency & Percentage \\
\hline \multirow[t]{2}{*}{ Gander } & Male & 66 & $58.9 \%$ \\
\hline & Female & 46 & $41.1 \%$ \\
\hline \multirow[t]{3}{*}{ Age in years } & $20-29$ years & 48 & $42.9 \%$ \\
\hline & $30-39$ years & 46 & $41.1 \%$ \\
\hline & $>39$ years & 18 & $16 \%$ \\
\hline \multirow[t]{3}{*}{ Marital status } & Single & 48 & $42.8 \%$ \\
\hline & Married & 59 & $52.7 \%$ \\
\hline & Others & 5 & $4.5 \%$ \\
\hline \multirow[t]{3}{*}{ Educational level } & $\begin{array}{l}\text { Secondary } \\
\text { education }\end{array}$ & 24 & $21.4 \%$ \\
\hline & BCS degree & 52 & $46.4 \%$ \\
\hline & Higher education & 36 & $32.2 \%$ \\
\hline \multirow[t]{2}{*}{ Years of experience } & $<7$ years & 81 & $72.4 \%$ \\
\hline & $\geq 7$ years & 31 & $27.6 \%$ \\
\hline \multirow{2}{*}{$\begin{array}{l}\text { Previous T\&D (for the last } 3 \\
\text { years) }\end{array}$} & Yes & 60 & $53.6 \%$ \\
\hline & No & 52 & $46.4 \%$ \\
\hline
\end{tabular}


Effect of Training and Development on Employee Performance...

\begin{tabular}{|l|l|l|l|}
\hline \multirow{2}{*}{$\begin{array}{l}\text { If "yes", (how many } \\
\text { programs) }\end{array}$} & One & 42 & $37.5 \%$ \\
\cline { 2 - 4 } & Two & 46 & $41 \%$ \\
\cline { 2 - 4 } & Three or more & 24 & $21.5 \%$ \\
\hline
\end{tabular}

\subsection{The answers of research questions}

\subsubsection{The first research question}

To answer the first research question (Is there aneffect of T\&D on Employee Performance in the Aqaba Special Economic Zone Authority?); an independentsamples t-test was conducted to compare the employee performance scores for trained and untrained employees, and the results concluded thatthere was a significant difference in scores for trained employees $(M=31.43, S D=4.382)$ and untrained employees $[M=25.54, S D=5.334 ; t(110)=6.42, P=.00]$, and according to (Cohen, 1988) guidelines the magnitude of the differences in the means was large effect (Eta. sq $=0.3$ ), so $(30 \%)$ of the employees performance isexplained by T\&D programs, as shown in table (3).

Table 3. Independent samples t-test

\begin{tabular}{|c|c|c|c|c|c|c|c|c|}
\hline \multicolumn{6}{|c|}{ T\&D programs } & \multirow{3}{*}{$\begin{array}{l}95 \% \mathrm{Cl} \text { for } \\
\text { Mean } \\
\text { Difference }\end{array}$} & \multirow[b]{3}{*}{$t$} & \multirow[b]{3}{*}{$\mathrm{df}$} \\
\hline \multicolumn{3}{|c|}{$\begin{array}{l}\text { Trained } \\
\text { employees }\end{array}$} & \multicolumn{3}{|c|}{$\begin{array}{l}\text { Un-trained } \\
\text { employees }\end{array}$} & & & \\
\hline $\mathrm{M}$ & SD & $\mathrm{n}$ & $M$ & SD & $\mathrm{n}$ & & & \\
\hline 31.4 & 4.38 & 6 & 25.5 & 5.33 & & 4.075, & 6.42 & \\
\hline 3 & 2 & 0 & 4 & 4 & 52 & 7.715 & $* *$ & 110 \\
\hline
\end{tabular}

\subsubsection{The second research question}

To answer the second research question (How did the employees evaluate the T\&D programs which provided by the authority?); the researcher analyze the responses of the participant for the questionnaire of "Training and development programs evaluation", by using the descriptive statistics (mean and standard deviation).

Analyzing the participants responds toward "Training and development programs evaluation questionnaire" revealed that the participants consider the T\&D programs which offered by the authority; are important and effective in developing employee performance, as they indicate that the paragraph "Does the training increase your motivation to the job you do?" to be evaluated as the most important point in the evaluation of the T\&D programs (Mean $=4.14, S D$. $=$ .711), and the lowest point in the evaluation questionnaire was "Does the 


\section{Journal of Business \& Management (COES\&RJ-JBM), 8(1), pp.20-34}

training program evaluate during or at the end of the program?" which have (Mean $=3.29$, SD. $=1.103$ ) in the participant evaluation for the programs (table 4).

Table 4. Mean and standard deviation for T\&D programs evaluation

\begin{tabular}{|l|l|l|l|l|}
\hline & Item & Mean & SD & $\begin{array}{l}\text { Sort } \\
\text { mean }\end{array}$ \\
\hline 1 & $\begin{array}{l}\text { Do you think the training program designed } \\
\text { based on the requirements of the job? Or } \\
\text { employee deficiency of ability for the job? }\end{array}$ & 3.74 & .951 & 5 \\
\hline 2 & $\begin{array}{l}\text { Is the type of training you have taken } \\
\text { applicable for the job after the training? }\end{array}$ & 3.80 & .894 & 3 \\
\hline 3 & $\begin{array}{l}\text { Do you have known the objective of the } \\
\text { training program? }\end{array}$ & 3.79 & .928 & 4 \\
\hline 4 & $\begin{array}{l}\text { Does the training increase your motivation } \\
\text { to the job you do? }\end{array}$ & 4.14 & .711 & 1 \\
\hline 5 & $\begin{array}{l}\text { Does training improves your skills, } \\
\text { knowledge, attitude change, new capability }\end{array}$ & 4.02 & .782 & 2 \\
\hline 6 & $\begin{array}{l}\text { Does the training lead you to be satisfied } \\
\text { with your job? }\end{array}$ & 3.80 & .948 & 3 \\
\hline 7 & $\begin{array}{l}\text { Do you think the method of training used by } \\
\text { the organization is effective } \\
\text { you to do your job as required? }\end{array}$ & 3.35 & .970 & 8 \\
\hline Do you think the expenditure for employee & 3.55 & 1.036 & 7 \\
\hline 10 & $\begin{array}{l}\text { Does the training program evaluate during } \\
\text { Do of the program? }\end{array}$ & 3.29 & 1.103 & 9 \\
\hline
\end{tabular}

\subsubsection{The third research question}

To answer the third research question (How did the employees see their level of performance?); the researcher analyze the responses of the participant for the 
questionnaire of "Self-evaluation of employee performance ", by using the descriptive statistics (mean and standard deviation).

Depending on the participants responds toward "Self-evaluation of employee performance scale" the results conclude that the participants evaluate their performance as an accepted to good level (Mean $=3.85$, SD. $=.883$ ), and the participants considers that "Plan and coordinate tasks / Follow up and complete tasks." had the best rating in the Self-evaluation of the employee performance" ( $($ Mean $=4.05, \mathrm{SD} .=.838)$, while the lowest rating in the Self-evaluation of the employee performance" Self-organization, time management skills and priority setting." (Mean = 3.65, SD. = .977), (table 5).

Table 5. Mean and SD. for Self-evaluation of employee performance

\begin{tabular}{|c|c|c|c|c|}
\hline & Item & Mean & SD & $\begin{array}{l}\text { Sort by } \\
\text { mean }\end{array}$ \\
\hline 1 & $\begin{array}{l}\text { My performance during the past } 6 \\
\text { months. }\end{array}$ & 3.87 & 1.042 & 5 \\
\hline 2 & $\begin{array}{l}\text { Attendance and commitment to } \\
\text { working hours. }\end{array}$ & 3.88 & .941 & 4 \\
\hline 3 & My current experience in my field. & 3.742 & .882 & 6 \\
\hline 4 & Job productivity. & 3.90 & .879 & 3 \\
\hline 5 & $\begin{array}{l}\text { Self-organization, time management } \\
\text { skills and priority setting. }\end{array}$ & 3.65 & .977 & 8 \\
\hline 6 & $\begin{array}{l}\text { Plan and coordinate tasks / Follow up } \\
\text { and complete tasks. }\end{array}$ & 4.05 & .838 & 1 \\
\hline 7 & Attention to detail. & 4.02 & .782 & 2 \\
\hline 8 & $\begin{array}{l}\text { Ability to manage stress, coping skills } \\
\text { and self-awareness. }\end{array}$ & 3.66 & .727 & 7 \\
\hline & $\begin{array}{l}\text { Total Mean and SD. for Self-evaluation } \\
\text { of employee performance }\end{array}$ & 3.85 & .883 & \\
\hline
\end{tabular}




\section{Discussion and conclusions}

The results in this study indicate that there a strong significant correlation between Training and Development programs and Employee Performance in the Aqaba Special Economic Zone Authority, this relation can be explain (30\%) of the employees performance as a result from T\&D programs. This positive effect of the T\&D programs on the employee's performance was reported by Sanyal \& Hisam (2018) in studying the employees in the Omani Banking Industry, and concludes that there was a positive influence on employee performance by T\&D programs which support the study results.

Furthermore, the results of this study could be supported by the results of previous study which was conducted in Nigeria by Yetunde and revealed that there was a significant relationship between T\&D programs and the employee performance, these result support the results of this study (Yetunde, 2018). Similar study support this study results, such as the result of Said, C.M. study which report that the training and development influence the employee performance in a significance degree (Said, 2015).

This study highlight on the effect of T\&D programs on the employee performance in the Aqaba Special Economic Zone Authority, and revealed that the T\&D programs can explain (30\%) of the employee performance. This indicates that there is a positive relationship between T\&D programs and employee performance. This relationship helps the organizations to invest in their employee skills by way of T\&D programsto collect the benefit of the employee's productivity.

Based on previous results, the researchers suggest a set of recommendations which are as follows:

a. Development of performance standards through the participation of employees.

b. "Self-organization, time management skills and priority setting" is most needed point to work on it by the HR on the next T\&D programs for the employees.

c. The budget for T\&D programs should be applied relative to the anticipated benefits to be achieved from it.

d. The frequency of T\&D programs should be improved and targeted at beneficent employee job performance.

e. The recurrence of T\&D programs provided to the employees should improve to guarantee that more employees have entrance to $T \& D$ programs. 
Effect of Training and Development on Employee Performance...

\section{References}

Abba, M.T. (2018). Effects of Training and Development on Employee Retention in Bauchi State Metropolis Banks. Operational Research, 4(1).

Abualoush, S., Bataineh, K., \& Alrowwad, A. (2018a). The Role of Knowledge Management Process and Intellectual Capital as Intermediary Variables between Knowledge Management Infrastructure and Organization Performance. Interdisciplinary Journal of Information, Knowledge, and Management, 13, 279309.

Abualoush, S., Obeidat, A., \& Tarhini, A. (2018b). The Role of Employees' Empowerment as an Intermediary Variable between Knowledge Management and Information Systems on Employees' Performance. VINE Journal of Information and Knowledge Management Systems, 48(2), 217-237.

Al-dalahmeh, M., Khalaf, R., \& Obeidat, B. (2018). The Effect of Employee Engagement on Organizational Performance via the Mediating Role of Job Satisfaction: The Case of IT Employees in Jordanian Banking Sector. Modern Applied Science, 12(6), 17-43.

Al-Dmour, R., Obeidat, B., \& Almajali, D. (2015). The Practice of HRIS Applications in Business Organizations in Jordan: An Empirical Study. 4th Scientific \& Research Conference on New Trends in Business, Management and Social Sciences (COES\&RJ-TK15/1).

Al-Syaidh, N., Al- Lozi, M., \& AlHarrasi, J. (2016). Transformational Leadership and its Role on the Effectiveness of Employees' Behavior: A Theoretical Study. Journal of Business \& Management (COES\&RJ-JBM), 4(1), 14-35.

Armstrong, M. (2009). Armstrong's Handbook of Human Resource Management Practice. $11^{\text {th }}$ Edition, Kogan Page Limited, London.

Asfaw, A.M., Argaw, M.D., \& Bayissa, L. (2015). The Impact of Training and Development on Employee Performance and Effectiveness: A Case Study of District Five Administration Office, Bole Sub-City, Addis Ababa, Ethiopia. Journal of Human Resource and Sustainability Studies, 3(04), 188.

Business Dictionary (2019). Available on: http://www.businessdictionary.com/definition/employee-performance.html

Elnaga, A., \& Imran, A. (2013). The Effect of Training on Employee Performance. European Journal of Business and Management, 5(4), 137-147.

Hafeez, U., \& Akbar, W. (2015). Impact of Training on Employees Performance (Evidence from Pharmaceutical Companies in Karachi, Pakistan). Business Management and Strategy, 6(1), 49-64. 
Hajir, J., Obeidat, B., \& Al-dalahmeh, M. (2015). The Role of Knowledge Management Infrastructure in Enhancing Innovation at Mobile Telecommunication Companies in Jordan. European Journal of Social Sciences, 50(3), 313-330.

Hassan, S. (2016). Impact of HRM Practices on Employee's Performance. International Journal of Academic Research in Accounting, Finance and Management Sciences, 6(1), 15-22.

Hidayat, R., \& Budiatma, J. (2018). Education and Job Training on Employee Performance. International Journal of Social Sciences and Humanities, 2(1), 171181.

Jain, T.K., \& Sharma, A. (2019). Impact of Training and Development on Employee Performance in Retail Sector: A Review Paper. SSRN Electronic Journal, 1-12.

Jaworski, C., Ravichandran, S., Karpinski, A.C., \& Singh, S. (2018). The Effects of Training Satisfaction, Employee Benefits, and Incentives on Part-time Employees' Commitment. International Journal of Hospitality Management, 74, 1-12.

Khan, U.R., Perveen, S., \& Shujat, F. (2017). The Impact of Training and Development on Staff Productivity of the Banking Sector Karachi Pakistan. Int. J. Multidiscip. Curr. Res, 5, 393-402.

Masa'deh, R. (2012). The Impact of Management Information Systems (MIS) on Quality Assurance (QA): A Case Study in Jordan. International Journal of Information, Business and Management, 4(2), 93-110.

Masa'deh, R., Obeidat, B., Zyod, D., \& Gharaibeh, A. (2015). The Associations among Transformational Leadership, Transactional Leadership, Knowledge Sharing, Job Performance, and Firm Performance: A Theoretical Model. Journal of Social Sciences (COES\&RJ-JSS), 4(2), 848-866.

Obeidat, B., Tarhini, A., \& Aqqad, N. (2017). The Impact of Intellectual Capital on Innovation via the Mediating Role of Knowledge Management: A Structural Equation Modelling Approach. International Journal of Knowledge Management Studies, 8(3-4), 273-298.

Padmasiri, M.D. (2018). The Relationship between Training and Development and Employee Performance of Executive Level Employees in Apparel Organizations. International Invention of Scientific Journal, 2(01).

Pradhan, R.K., \& Jena, L.K. (2017). Employee Performance at Workplace: Conceptual Model and Empirical Validation. Business Perspectives and Research, 5(1), 69-85. 
Said, C. M. (2015). An assessment on the Impact of Training and Development on Employees' Performance at work: A case study of NSSF Headquarters (Doctoral dissertation), Mzumbe University, Tanzania.

Sanyal, S., \& Hisam, M.W. (2018). Impact of Training and Development on the Performance of Employees-A Comparative Study on Select Banks in Sultanate of Oman. International Journal of Scientific Research and Management, 6(03).

Shen, J., \& Tang, C. (2018). How does Training Improve Customer Service Quality? The Roles of Transfer of Training and Job Satisfaction. European Management Journal, 36(6), 708-716.

Sung, S.Y., \& Choi, J.N. (2018). Effects of Training and Development on Employee Outcomes and Firm Innovative Performance: Moderating Roles of Voluntary Participation and Evaluation. Human Resource Management, 57(6), 1339-1353.

Yetunde, E. (2018). Impact of Training and Development on Employee Performance and Productivity among Members of Staff: Case Study of Kogi State Polytechnic. Academy of Social Science Journal, 3(11), 1242-1248. 